\title{
ALLELOPATHIC ACTIVITY OF Amburana cearensis SEED EXTRACTS ON MELON EMERGENCE ${ }^{1}$
}

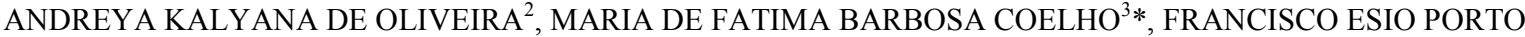

DIÓGENES ${ }^{2}$

\begin{abstract}
Amburana cearensis is a species rich in coumarin, a phenolic compound that is a natural inhibitor of the germination process. In Caatinga, this species occurs in areas where melons are cultivated, and even after deforestation, they may be present in the soil seed bank. The aim of this study was to investigate the allelopathic activity of $A$. cearensis aqueous seed extract fractions on the emergence of melons and to carry out photochemical analyses of the extracts. Four experiments were carried out based on the fractionation of the seed extract: E1 - hexane fraction, E2 - dichloromethane fraction, E3 - ethyl acetate fraction, and E4 - aqueous fraction. The statistical design was completely randomized, with four replicates, each having 20 seeds. The treatments were composed of different extract concentrations $(1,0.5,0.25,0.125$, and $0 \%)$ and phytochemical prospecting of the extracts obtained during fractionation was performed. The extracts obtained from the hexane fraction affected the emergence and initial development of melon seedlings. The dichloromethane, ethyl acetate, and aqueous extracts had negative effects on the formation of dry matter, shoots, and roots, with the highest concentrations prompting the most negative effects. Coumarin was present in all extracts, but its concentration was highest in the hexane fraction, which was consequently characterized as highly phytotoxic during the bioassays.
\end{abstract}

Keywords: Allelochemistry. Coumarin. Fractionation of extracts. Phytochemical prospection.

\section{ATIVIDADE ALELOPÁTICA DO EXTRATO AQUOSO DE SEMENTES DE Amburana cearensis NA EMERGÊNCIA DE MELÃO}

RESUMO - Amburana cearensis é uma espécie rica em cumarina, composto fenólico inibidor natural do processo de germinação. A espécie ocorre na Caatinga em áreas em que o melão é cultivado, e mesmo após o desmatamento, pode estar presente no banco de sementes. O objetivo desse estudo foi averiguar a atividade alelopática de frações de extrato aquoso de sementes de $A$. cearensis sobre a emergência de melão e realizar a prospecção fotoquímica nos extratos. Foram conduzidos quatro experimentos com o fracionamento do extrato de sementes: E1 - fração hexânica, E2 - fração diclorometano, E3 - fração acetato de etila e E4 - fração aquosa. $\mathrm{O}$ delineamento estatístico foi inteiramente casualizado com quatro repetições com vinte sementes. Os tratamentos foram compostos das concentrações $1 ; 0,5 ; 0,25 ; 0,125$ e $0 \%$, correspondentes de cada extrato. Foi realizada a prospecção fitoquímica dos extratos obtidos no fracionamento. As características avaliadas foram emergência e índice de velocidade de emergência, porcentagem de plântulas normais e anormais, comprimento de parte aérea e raiz e matéria seca. Os extratos obtidos a partir da fração hexânica afetam os processos de emergência e desenvolvimento inicial das plântulas de melão. Os extratos diclorometano, acetato de etila e aquoso agem na formação de matéria seca, parte aérea e raiz de melão, com efeitos negativos na maior concentração do extrato. A cumarina predomina em todos os extratos. $\mathrm{O}$ extrato hexânico apresenta maior concentração de cumarina e é altamente fitotóxico.

Palavras-chave: Aleloquímicos. Cumarina. Fracionamento de extratos. Prospecção fitoquímica.

\footnotetext{
${ }^{*}$ Corresponding author

${ }^{1}$ Received for publication in $07 / 26 / 2019$; accepted in $11 / 12 / 2019$

Paper extracted from the doctoral thesis of the first author.

${ }^{2}$ Department of Phytotechnics, Universidade Federal Rural do Semi-Árido, Mossoró, RN, Brazil; oliver_andreya@yahoo.com.br ORCID:0000-0003-2010-7158, esioporto@gmail.com - ORCID: 0000-0003-0786-5165.

${ }^{3}$ Postgraduate Program in Tropical Agriculture, Universidade Federal de Mato Grosso, Cuiabá, Mato Grosso, Brazil; coelhomfstrela@gmail.com - ORCID:0000-0003-1393-2504.
} 


\section{INTRODUCTION}

Amburana cearensis (Allem) A. C. Smith is a tree that occurs in the Northeast (Caatinga) and Central-West regions of Brazil (ALMEIDA et al., 2010). Its seeds are used in traditional medicine as antispasmodics, and emmenagogues, and to treat respiratory disorders, e.g., bronchitis, asthma, flu, and colds (LORENZI, 2014).

A. cearensis is rich in coumarin, a phenolic compound that inhibits the germination process. The presence of coumarin in the integument is responsible for controlling the oxygen intake inside the seed, as it is able to fix the $\mathrm{O}_{2}$ absorbed by the seeds, thus preventing its accumulation into the seeds (FELIX, 2007). Compounds such as coumarin are called allelochemicals and are involved in a process called allelopathy, which is a biochemical interaction between certain plants and microorganisms. These direct or indirect interactions are harmful or beneficial, and chemicals are released into the medium (RICE, 1984).

Allelochemicals are secondary metabolites derived from the acetate or shikimate routes, or a combination thereof. These compounds include alkaloids, anthocyanins, catechins, chalcones, coumarins, steroids, phenols, flavones, flavonols, flavonones, quinones, resins, saponins, tannins, terpenoids, and xanthones. They can be released into the air, excreted from the root, or carried to the soil by rainwater, which washes the aerial parts of the plant, interfering with seed conservation, dormancy, germination, seedling growth, vegetative vigor of adult plants, and also influence species competition (YAMAGUSHI; GUSMAN; VESTENA, 2011; TAIZ et al., 2017).

Allelopathic compounds can also function as natural herbicides, providing a much better alternative to the harmful effects of synthetic herbicides (JABRAN, 2017). In this regard, several efforts have been made in recent years to identify allelopathic properties of substances that offer new and excellent opportunities to diversify agricultural weed control (SOUZA FILHO; FONSECA; ARRUDA, 2005).

The fractionation of extracts facilitates the identification of compounds that could have allelopathic effects. During fractionation, chemicals are extracted from crushed plant parts and placed in contact with water or organic solvents (ethanol, ethyl acetate, acetone, chloroform, etc.). After filtration, the extracts containing allelopathic compounds are obtained (TAIZ et al., 2017).

Aqueous seed extracts of Ziziphus joazeiro at the highest concentrations (75 and 100\%), affected the percentage and rate of lettuce germination and yielded abnormal seedlings (COELHO et al., 2011). Additionally, the aqueous bark extract (75 and $100 \%$ ) of Mimosa tenuiflora affected the development of lettuce plants but did not reduce lettuce germination in relation to the control (SILVEIRA; MAIA; COELHO, 2012).

In studies concerning Amburana cearensis, Caesalpinia ferrea, Erythrina mulungu, and Ziziphus joazeiro, it was found that extracts from different plant organs, depending on the concentration $(1,0.5$, $0.25,0.125$, and $0 \%$ ), can affect both the emergence and growth-related characteristics of melon seedlings (OLIVEIRA et al., 2016). According to these authors, the aqueous extract of $A$. cearensis seeds prevented the emergence of melon seedlings at all concentrations $(1,0.5,0.25$, and $0.125 \%)$ and increasing concentrations of the aqueous leaf extracts caused a proportional increase in seedling abnormalities.

Thus, the present study aimed to evaluate the allelopathic activity of Amburana cearensis seed extract fractions on melon emergence and perform photochemical prospecting on the extracts.

\section{MATERIALS AND METHODS}

\section{Chromatographic fractionation of the $A$. cearensis seed extract}

The aqueous crude extract obtained from $A$. cearensis seeds was fractionated following an increasing order of polarity (hexane, dichloromethane, and ethyl acetate). This was done to separate the secondary metabolites contained in the crude extract into groups, and to estimate the fractions that would have the greatest effect on melon development.

After the separation and drying of the hexane, dichloromethane, and ethyl acetate fractions, the preparation of three suspensions commenced by diluting the dry masses $(0.5414 \mathrm{~g}$ of the hexane fraction, $0.3601 \mathrm{~g}$ of the dichloromethane fraction, and $0.8427 \mathrm{~g}$ of the ethyl acetate fraction) in an initial volume of the crude extract $(675 \mathrm{~mL})$. The aqueous fraction was obtained by drying the material of the remaining fraction in a water bath to promote the removal of solvent residues. Distilled water was then added at a volume corresponding to the initial volume $(675 \mathrm{~mL})$. Once prepared, the suspensions were heated at $60{ }^{\circ} \mathrm{C}$ for $30 \mathrm{~min}$, sonicated (for better solubilization), and then filtered.

Then, $\mathrm{pH}$ and electrical conductivity were determined. From these values, the osmotic potential was calculated using the formula proposed by Ayers and Westcot (1994).

\section{Bioassays with $A$. cearensis seeds}

As testing material, we used the Iracema melon seeds (Cucumis melo L., $\mathrm{S}_{1}$ category hybrids) that were obtained commercially from SAKATA (Sakata Seed America, Morgan Hill, CA, USA). An initial emergency test was performed on washed 
sand to verify their emergence, obtaining a value of $98.75 \%$.

The experimental design was completely randomized with four replications, having twenty seeds each. Hexane, dichloromethane, ethyl acetate, and the aqueous fractions constituted the four experimental trials, in five concentrations $(1,0.5$, $0.25,0.125$, and $0 \%$ ). Each experimental plot consisted of plastic boxes (depth $17 \mathrm{~cm}$, width 9.5 $\mathrm{cm}$, and height $4.3 \mathrm{~cm}$ ) that had been sterilized with alcohol, containing $400 \mathrm{~g}$ of washed and sterilized sand.

Each experimental unit was moistened with $50 \mathrm{~mL}$ of the extract, and its contents were revolved to ensure a uniformity of moisture within the plot and leveled with the aid of a spatula. After that, circular holes ( $1 \mathrm{~cm}$ wide and $6.5 \mathrm{~cm}$ deep) were drilled, where the 20 seeds were evenly distributed. The plastic boxes were stored at $25{ }^{\circ} \mathrm{C}$ for germination, with a $24 \mathrm{~h}$ photoperiod for 8 days (BRASIL, 2009).

The beginning of seedling emergence was marked by the emission of cotyledon and the emerged seeds were counted daily. Seedling evaluations occurred on the eighth day after sowing, classifying them as normal or abnormal, according to criteria described in Brasil (2009). The shoot and root measurements of all normal seedlings were done using a ruler. For the dry mass determination the of the normal seedlings, a forced air circulation oven was used at an average temperature of $65^{\circ} \mathrm{C}$, for 24 $\mathrm{h}$. The materials were then placed in a desiccator, to promote cooling without exchanging heat with the environment, and soon after, the materials were weighed using a precision scale. Seedling abnormalities were also characterized according to Brasil (2009).

The analyzed variables were the percentage of emergence, percentage of normal and abnormal seedlings, root length, and shoot length. The emergence speed index (ESI) was calculated according to Maguire (1962). An analysis of variance was performed, and the means were compared using Tukey's test at a 5\% probability.

\section{Phytochemical prospecting of $A$. cearensis seed extracts}

Preliminary prospecting methodology was used to identify the secondary metabolite classes present in the extracted fractions (hexane, dichloromethane, ethyl acetate, and aqueous), where phenols and tannins, anthocyanins, anthocyanidins, flavonoids leucocyanins, catechins flavones, flavonols, flavanones, xanthones, steroids triterpenoids, saponin, alkaloids, quinones, and coumarins were tested.

The extracts used in the prospecting corresponded to $50 \mathrm{~mL}$ aliquots taken from the suspensions of each fraction, obtained during the fractionation process. These were placed to dry at 60 ${ }^{\circ} \mathrm{C}$ in a water bath, until their dry masses were obtained (hexane $0.0177 \mathrm{~g}$, ethyl acetate $0.5205 \mathrm{~g}$, dichloromethane $0.0545 \mathrm{~g}$, and aqueous $2.9863 \mathrm{~g}$ ). These masses were diluted in the same initial volume $(50 \mathrm{~mL})$ of a hydroalcoholic solution, giving rise to the fractions that were employed during the determination of the prospecting tests. For this, the volume of each extract was divided into two $10 \mathrm{~mL}$ portions in labeled beakers; these were used for the determination of steroids, triterpenoids and saponins, and alkaloids.

The other aliquots were fractionated into seven $2.5 \mathrm{~mL}$ portions in test tubes (numbered from one to seven), to determine the presence of phenols and tannins; anthocyanins, anthocyanidins and flavonoids; leucoanthocyanidins, catechins and flavones; and flavonols, flavanones, flavanonols, and xanthones. The remaining amounts were concentrated in a water bath until their volume reduced to half, after which they were filtered and their $\mathrm{pH}$ was adjusted (to 4) for subsequent use in the determination of quinone and coumarin.

All tests were performed following the methodology of Matos (2009). Results were considered positive based on the formation of precipitates and the appearance of color, and were classified as weakly, moderately, and strongly positive, according to the color intensity. Results were considered negative in case of the absence of color.

\section{RESULTS AND DISCUSSION}

\section{Fractionation of $A$. cearensis seed extract}

The osmotic potential and $\mathrm{pH}$ of the different concentrations of hexane, dichloromethane, ethyl acetate, and the aqueous fractions of $A$. cearensis crude seed extracts, were within the normal ranges; therefore, these factors were unlikely to be responsible for the possible changes in melon germination (Table 1). 
Table 1. Physicochemical characteristics of the aqueous extract fraction of Amburana cearensis (Fr. Allem.) A.C. Smith seeds used in bioassays for the evaluation of the allelopathic potential on melon (Cucumis melo L.) seeds. $\mathrm{pH}$ and $\mathrm{PO}$ (osmotic potential).

\begin{tabular}{lcc}
\hline \multirow{2}{*}{ Concentration (\%) } & \multicolumn{3}{c}{ Hexane Fraction } & PH (Mpa) \\
\cline { 2 - 3 } 0.5 & 6.25 & -0.00401 \\
0.25 & 6.29 & -0.00401 \\
0.125 & 6.65 & -0.00401 \\
0 & 6.77 & -0.00474 \\
\hline \multicolumn{1}{l}{ DCM Fraction (Dichloromethane) } \\
\hline 1 & 6.39 & 0 \\
0.5 & 6.32 & -0.00438 \\
0.25 & 6.34 & -0.00401 \\
0.125 & 6.49 & -0.00365 \\
0 & 5.90 & -0.00365 \\
\hline & & 0 \\
\hline 1 & Ethyl Acetate Fraction & -0.02809 \\
0 & 5.37 & 0 \\
\hline 1 & 5.90 & -0.17325 \\
0 & Water Fraction & 0 \\
\hline
\end{tabular}

The evaluation of $\mathrm{pH}$ and osmotic potential of the plant extracts is fundamental, as extreme values of both can act on the seeds/seedlings and mask the allelopathic effect (TAIZ et al. 2017). In this work, both $\mathrm{pH}$ and osmotic potential of the extracts were within an acceptable range and would not have interfered with melon seed germinability.

\section{Bioassays with $A$. cearensis seeds}

After evaluating which of the different fractions (hexane, dichloromethane, ethyl acetate, and aqueous) could extract more harmful secondary metabolites from the crude extracts we found that the hexane and dichloromethane fractions of the $A$. cearensis seed extract affected the emergence processes (percentage and emergence speed index) and initial growth (percentage of normal seedlings, shoot length, root length, and dry mass) of melon seedlings significantly. The hexane fraction in the highest concentrations ( 1 and $0.5 \%$ ) prevented the emergence of melon seeds, while dichloromethane, ethyl acetate, and the aqueous fractions did not affect the emergence (Table 2).

The activity of the extract fractions depends on the presence of the allelopathic compounds, which in turn depends on the species. Thus, results that are different from the present study, were found by Souza Filho et al. (2010), who observed that hexane extracts of leaves and bark of Copaifera duckei, C. martii, and C. reticulata presented low allelopathic activity, inhibiting the seed germination of Mimosa pudica, but the biggest effect was on root development. On the contrary, the ethanolic extract of leaves and branches of $C$. martii and C. reticulata had high potential to inhibit seed germination. Malheiros et al. (2014) found that ethanolic extracts of the leaf and stem of Lafoensia pacari did not affect lettuce seeds at any concentration used.

The effects of ethyl acetate and the aqueous fractions on the emergence and initial development was of minor significance, as only the characteristics of the DM, ESI, and RL were affected in the presence of these extracts. An allelopathy study with Annona crassiflora, found that two substances (glycosylated stigmasterol and glycosylated sitosterol), present in the crude extracts (by ethyl acetate) of $A$. crassiflora seeds, reduced the radicle and hypocotyl development of Euphorbia heterophylla, showing an allelopathic effect on this weed (INOUE et al., 2010)

Statistical differences for seedling DM and RL could be detected in the extracts obtained from the ethyl acetate fraction, where the control average was approximately twice the average obtained for the $1 \%$ concentration (Table 2 ).

Analysis of the SL and RL of the melon seedlings, subjected to the different fractions (hexane, dichloromethane, ethyl acetate, and aqueous), revealed that except for the lowest concentration $(0.125 \%)$, which did not differ from the control the $0.25 \%$ hexane extract decreased these values. Seedling RL, however, was reduced by all extract dilutions. Interestingly, these caused an accelerated stimulation of the base tissues in the stem, which in some seedlings extended to the beginning of the main root. 
Table 2. Characteristics of the emergence percentage (EP), emergence speed index (ESI), percentage of normal seedlings (PNS), percentage of abnormal seedlings (PAS), dry matter (DM), shoot length (SL) and root length (RL), from melon (Cucumis melo L.) seeds treated with different fractions (hexane, dichloromethane, ethyl acetate, and aqueous) of the aqueous extract of Amburana cearensis (Fr. Allem.) A.C. Smith seeds used at different concentrations.

\begin{tabular}{|c|c|c|c|c|c|c|c|}
\hline $\begin{array}{l}\text { Concentration } \\
(\%)\end{array}$ & EP & ESI & PNS & PAS & $\mathrm{DM}(\mathrm{g})$ & $\mathrm{SL}(\mathrm{cm})$ & $\mathrm{RL}(\mathrm{cm})$ \\
\hline \multicolumn{8}{|c|}{ Hexane Fraction } \\
\hline 1 & $0.00 \mathrm{c}$ & $0.00 \mathrm{c}$ & $0.00 \mathrm{c}$ & $0.00(0.79)^{1} \mathrm{a}$ & $0.00 \mathrm{~b}$ & $0.00 \mathrm{c}$ & $0.00 \mathrm{c}$ \\
\hline 0.5 & $0.00 \mathrm{c}$ & $0.10 \mathrm{c}$ & $0.00 \mathrm{c}$ & $0.00(0.79) \mathrm{a}$ & $0.00 \mathrm{~b}$ & $0.00 \mathrm{c}$ & $0.00 \mathrm{c}$ \\
\hline 0.25 & $95.00 \mathrm{~b}$ & $3.28 \mathrm{~b}$ & $88.75 \mathrm{~b}$ & $6.25(0.85) \mathrm{a}$ & $0.56 \mathrm{a}$ & $10.40 \mathrm{~b}$ & $9.72 \mathrm{~b}$ \\
\hline 0.125 & $100.00 \mathrm{a}$ & $3.66 \mathrm{a}$ & $93.75 \mathrm{ab}$ & $6.25(0.85) \mathrm{a}$ & $0.74 \mathrm{a}$ & $10.92 \mathrm{ab}$ & $11.67 \mathrm{ab}$ \\
\hline 0 & $100.00 \mathrm{a}$ & $3.61 \mathrm{a}$ & $100.00 \mathrm{a}$ & $0.00(0.79) \mathrm{a}$ & $0.78 \mathrm{a}$ & $11.33 \mathrm{a}$ & $12.88 \mathrm{a}$ \\
\hline $\mathrm{CV}^{2}(\%)$ & 3.09 & 4.14 & 6.26 & 4.88 & 32.32 & 5.06 & 14.86 \\
\hline $\mathrm{DMS}^{3}$ & 4.00 & 0.19 & 7.72 & 0.09 & 0.29 & 0.72 & 2.22 \\
\hline \multicolumn{8}{|c|}{ Dichloromethane Fraction } \\
\hline 1 & $88.75 \mathrm{a}$ & $3.42 \mathrm{a}$ & $94.45 \mathrm{a}$ & $5.55(0.84)^{1} \mathrm{a}$ & $0.36 \mathrm{c}$ & $12.50 \mathrm{~b}$ & $11.45 \mathrm{~b}$ \\
\hline 0.5 & $91.25 \mathrm{a}$ & $3.69 \mathrm{a}$ & $97.12 \mathrm{a}$ & $2.88(0.82) \mathrm{a}$ & $0.43 \mathrm{bc}$ & $12.29 \mathrm{~b}$ & $11.12 \mathrm{~b}$ \\
\hline 0.25 & $97.50 \mathrm{a}$ & $3.95 \mathrm{a}$ & $96.12 \mathrm{a}$ & $3.89(0.83) \mathrm{a}$ & $0.47 \mathrm{abc}$ & $13.77 \mathrm{a}$ & $12.36 \mathrm{ab}$ \\
\hline 0.125 & $100.00 \mathrm{a}$ & $3.86 \mathrm{a}$ & $100.00 \mathrm{a}$ & $0.00(0.79) \mathrm{a}$ & $0.60 \mathrm{ab}$ & $12.12 \mathrm{~b}$ & $12.45 \mathrm{ab}$ \\
\hline 0 & $97.50 \mathrm{a}$ & $3.84 \mathrm{a}$ & $100.00 \mathrm{a}$ & $0.00(0.79) \mathrm{a}$ & $0.62 \mathrm{a}$ & $12.05 \mathrm{~b}$ & $12.99 \mathrm{a}$ \\
\hline $\mathrm{CV}^{2}(\%)$ & 4.18 & 6.94 & 4.62 & 2.14 & 5.91 & 7.70 & 4.15 \\
\hline $\mathrm{DMS}^{3}$ & 13.67 & 0.63 & 7.26 & 0.07 & 0.19 & 1.09 & 1.36 \\
\hline \multicolumn{8}{|c|}{ Ethyl Acetate Fraction } \\
\hline 1 & $93.75 \mathrm{a}$ & $3.89 \mathrm{a}$ & $93.75 \mathrm{a}$ & $0.00(0.80) \mathrm{a}$ & $0.48 \mathrm{~b}$ & $12.34 \mathrm{a}$ & $6.94 \mathrm{~b}$ \\
\hline 0 & $95.00 \mathrm{a}$ & $4.20 \mathrm{a}$ & $95.00 \mathrm{a}$ & $0.25(0.79) \mathrm{a}$ & $1.03 \mathrm{a}$ & $12.56 \mathrm{a}$ & $14.06 \mathrm{a}$ \\
\hline $\mathrm{CV}^{2}(\%)$ & 6.40 & 9.50 & 6.40 & 2.22 & 23.89 & 3.62 & 15.10 \\
\hline $\mathrm{DMS}^{3}$ & 10.45 & 0.67 & 10.45 & 3.06 & 0.31 & 0.78 & 2.74 \\
\hline \multicolumn{8}{|c|}{ Water Fraction } \\
\hline 1 & $90.00 \mathrm{a}$ & $3.52 \mathrm{~b}$ & $89.00 \mathrm{a}$ & $0.00(0.80) \mathrm{a}$ & $0.58 \mathrm{a}$ & $12.67 \mathrm{a}$ & $5.70 \mathrm{~b}$ \\
\hline 0 & $95.00 \mathrm{a}$ & $4.20 \mathrm{a}$ & $95.00 \mathrm{a}$ & $0.25(0.79) \mathrm{a}$ & $0.48 \mathrm{a}$ & $12.34 \mathrm{a}$ & $14.06 \mathrm{a}$ \\
\hline $\mathrm{CV}^{2}(\%)$ & 7.64 & 8.62 & 6.57 & 2.22 & 12.26 & 4.32 & 15.94 \\
\hline $\mathrm{DMS}^{3}$ & 12.23 & 0.58 & 10.44 & 3.06 & 0.11 & 0.94 & 2.72 \\
\hline
\end{tabular}

Means followed by the same letter in the columns do not differ from each other, based on the Tukey test at a $5 \%$ significance level. ${ }^{1}$ The values in parentheses in the PAS column correspond to the averages of the original data transformed to arcosen $[\operatorname{root}(\mathrm{x} / 100)+0.5)] \cdot{ }^{2} \mathrm{CV}=$ Coefficient of variation. ${ }^{3} \mathrm{DMS}=$ Minimum significant difference.

When the effects of ethyl acetate and aqueous extracts were evaluated, it was observed that there were no statistical differences between the control and the highest concentrations of the extracts for the $\mathrm{SL}$, but the root length was reduced by $50 \%$ in the presence of the ethyl acetate extract, and more than $50 \%$ by the aqueous extract. Additionally, this extract caused the thickening of the secondary roots.

\section{Prospecting the constituents of the hydroalcoholic A. cearensis seed extracts}

The concentrations of coumarin, flavones, flavonoids, and xanthones were higher in the ethyl acetate and aqueous fractions. These fractions were also the only ones with phenol constituents and flabobenic tannins (Table 3). 
Table 3. Qualitative phytochemical analysis of the plant constituents of the extracts obtained in the hexane, dichloromethane, ethyl acetate, and aqueous fractions of the crude A. cearensis (Fr. Allem.) A. C. Smith.

\begin{tabular}{llccc}
\hline Constituents & Hexane & Dichloromethane & Ethyl Acetate & Water \\
\hline $\begin{array}{l}\text { Phenols and Tannins } \\
\text { Anthocyanins, Anthocyanidins Flavones, }\end{array}$ & Negative & Pegative & $(+)$ T. F. & $(+)$ T. F. \\
$\begin{array}{l}\text { Flavonols, and Xanthones } \\
\text { Leukocyanidins, Catechins, and Flavones }\end{array}$ & Negative & Positive & Positive $^{+++}$ & Positive $^{++++}$ \\
Flavonols, Flavanonols, and Xanthones & Negative & Negative & Negative & Negative \\
Steroids and Triterpenoids & Negative & Negative & Negative & Negative \\
Saponins & Negative & Negative & Negative & Negative \\
Alkaloid & Negative & Negative & Negative & Negative \\
Quinones & Negative & Negative & Negative & Negative \\
Coumarin & Strong & Positive & Weak positive & Moderate Positive \\
& positive & & & \\
\hline
\end{tabular}

+ Corresponds to the low presence of the compounds (flavone, flavanonols, and xanthones). ++ Corresponds to the moderate presence of the compounds (flavone, flavanonols, and xanthones). +++ Corresponds to the presence of the compounds (flavone, flavanonols, and xanthones). ++++ Corresponds to the strong presence of the compounds (flavone, flavanonols, and xanthones). (+) T.F. positive for flabobenic tannins.

The presence of coumarin was found in all extracts, regardless of the fraction. However, a higher intensity of fluorescent staining was observed in the hexane and dichloromethane fractions, which means that these fractions contained more coumarin than the others. Thus, coumarin may have been responsible for the observed allelopathic effects. Canuto, Lima, and Silveira (2010) reported the isolation of six new amburosides and the new 6coumaril protocatecuate from $A$. cearensis seeds and bark, along with coumarin, 6-hydroxycoumarin, isocampferid, formononetin, vanillic acid, amburoside A, and (E)-o-coumaric acid.

Over the last six decades several studies have emerged worldwide, aiming to identify, (through phytochemical prospecting) species with the potential to supply chemical molecules with relevant properties that are of agricultural interest (FORMAGIO et al., 2010; RODRIGUES et al., 2010; PEREIRA et al., 2018).

Generally, prospective researches are based on the hypothesis that substances in the extracts will express their allelopathic potential by affecting the prospective plant. This approach, however, shows the need for further studies that will focus more on isolating and identifying the chemical compounds involved in the allelopathic activity.

\section{CONCLUSIONS}

The process of emergence and initial development in the melon seedlings are affected the most by extracts obtained from the hexane fraction. Coumarin was present in a higher concentration in this fraction, which is phytotoxic.

\section{REFERENCES}

ALMEIDA, J. R. G. S. et al. Amburana cearensis uma revisão química e farmacológica. Scientia Plena, 6: 1-8, 2010.

AYERS, R. S.; WESTCOT, D. W. Water Quality for Agriculture, Irrigation and Drainage Paper, 29 Rev. 1 (Reprinted 1989, 1994). 1994.

BRASIL. Ministério da Agricultura e Reforma Agrária. DNPV. Divisão de Sementes e Mudas. Regras para Análise de Sementes. Brasília: Mapa, 2009, 399 p.

CANUTO, K. M.; LIMA, M. A. S.; SILVEIRA, E. R. Amburosides $\mathrm{C}-\mathrm{H}$ and 6-O-protocatechuoyl coumarin from Amburana cearensis. Journal of the Brazilian Chemical Society, 21: 1746-1753, 2010.

COELHO, M. F. B. et al. Atividade alelopática de extrato de sementes de juazeiro. Horticultura Brasileira, 29: 108-111, 2011.

FELIX, R. A. Z. et al. Efeitos Alelopáticos da Amburana cearensis L. (Fr.All.) AC Smith na Germinação de Sementes de Alface (Lactuca sativa L.) e de Rabanete (Raphanus sativus L.). Revista Brasileira de Biociências, 5: 138-140, 2007.

FORMAGIO, A. S. N. et al. Potencial alelopático de cinco espécies da família Annonaceae. Revista Brasileira de Biociências, 8: 349-354, 2010.

INOUE, M. H. et al. Avaliação do potencial alelopático de substâncias isoladas em sementes de araticum (Annona crassiflora). Planta Daninha, 28: 735-741, 2010. 
JABRAN, K. Manipulation of allelopathic crops for weed control. Dordrecht: Springer, 1 ed. 2017, 87 p.

LORENZI, H. Árvores Brasileiras: manual de identificação e cultivo de plantas arbóreas nativas do Brasil. 6. ed. Nova Odessa, SP: Instituto Plantarum, 2014. 384 p.

MAGUIRE, J. D. Speeds of germination-aid selection and evaluation for seedling emergence and vigor. Crop Science, 2: 176-177, 1962.

MALHEIROS, R. S. P. et al. Atividade alelopática de extratos de Lafoensia pacari A. ST.-HIL. sobre Lactuca sativa L. e Zea mays L. em condições de laboratório. Revista Brasileira de Agroecologia, 9: 185-194, 2014.

MATOS, J. F. A. Introdução a fitoquímica experimental. 3. ed. Fortaleza, CE: Edições UFC, 2009. $150 \mathrm{p}$.

OLIVEIRA, A. K. et al. Alelopatia de extratos de espécies da caatinga sobre sementes de meloeiro. Semina: Ciências Agrárias, 37: 557-566, 2016.

PEREIRA, K. C. L. et al. Potencial alelopático do extrato etanólico de Anacardium humile A.St.-Hil. (cajuzinho-do-cerrado) na germinação e formação de plântulas de Lactuca sativa L. (alface), Lycopersicon esculentum Mill. (tomate) e Senna obtusifolia (L.) Irwin \& Barneby (fedegoso). Gaia Scientia, 12: 144$160,2018$.

RICE, E. L. Allelopathy. London: Academic Press, 1984. 413 p.

RODRIGUES, I. M. C. et al. Prospecção química de compostos produzidos por Senna alata com atividade alelopática. Planta Daninha, 28: 1-12, 2010.

SILVEIRA, P. F.; MAIA, S. S. S.; COELHO, M. F. B. Potencial alelopático do extrato aquoso de folhas de Mimosa tenuiflora (Willd.) Poir. na germinação de Lactuca sativa 1. Bioscience Journal, 28: 472477, 2012.

SOUZA FILHO, A. P. S.; FONSECA, M. L.; ARRUDA, M. S. P. Substâncias químicas com atividades alelopáticas presentes nas folhas de Parkia pendula (Leguminosae). Planta Daninha, 23: 565-573, 2005.

SOUZA FILHO, A. P. S. et al. Atividade alelopática de extratos brutos de três espécies de Copaifera (Leguminosae-Caesalpinioideae). Planta Daninha,
28: 743-751, 2010.

TAIZ, L. et al. Fisiologia e Desenvolvimento Vegetal. 6. ed. São Paulo, SP: Artmed, 2017. 888 p.

YAMAGUSHI, M. Q.; GUSMAN, G. S.; VESTENA, S. Allelopathic effect of aqueous extracts of Eucalyptus globulus Labill. and of Casearia sylvestris Sw. on crops. Semina: Ciências Agrárias, 32: 1361-1374, 2011. 